УДК 373.5.016:811.111 [07]

DOI: https://doi.org/10.35619/iiu.v0i9.134

Olha Bezkorovaina

Doctor in Pedagogy, Professor, Head at the Department of Methodology of Teaching Foreign Languages, Rivne State University of the Humanities,

Rivne, Ukraine

ORCID: 0000-0001-7144-9946, e-mail:olg2686@gmail.com

Tetiana Demchuk Student of the first level of higher education "Bachelor" at the Foreign Philology Faculty, Rivne State University of the Humanities,

Rivne, Ukraine

ORCID: 0000-0003-0783-6540,

e-mail:demchuktania.dr@gmail.com

\title{
FORMATION OF ENGLISH LANGUAGE COMPETENCE IN READING ON THE HIGHER DEGREE OF STUDYING ENGLISH IN INSTITUTIONS OF SECONDARY EDUCATION
}

\begin{abstract}
This article is devoted to the problem of the formation of the competence of the English language reading on upper degree; the general characteristics of competence of reading in English language on the upper degree are given; the aims of the competence of reading in English language are defined; examples of exercises, characteristics of means and the issue of the assessment of the competence of reading in English language are described;the specifics of competency education in English lessons are determined.

The article proves that one of the types of communicative activities in foreign language classes is reading. There is considered the general characteristics of foreign language competence in reading, the purpose of its formation in students; descriptions of exercises and tasks are given; the means of formation the competence in reading at the highest level and control the level of its formation are described.

The article reveals the features of the aspects of reading and basic levels of understanding of the text; The necessary conditions for the formation of the competence of reading English at the highest level have been clarified; the theoretical basis of the methodology of reading at lessons should have general educative laws and principles for the construction of any learning process. It is proved in the article that the ability to read allows pupils in their further work and training to use literature in a foreign language with the aim to find information on the speciality, to satisfy their readership or creative interests, and to improve the skills of oral speech.

For solving the problems general scientific methods of theoretical and empirical research which mutually complement each other and provided the possibility of comprehensive knowledge of the subject of research were used. Methods (analysis of psychological and pedagogical literature, comparison and generalization of facts) were used at the stage of theoretical research. Other methods were decisive in developing a set of exercises for teaching English language instruction for senior students.
\end{abstract}


Key words: English language competence in reading, language awareness, stages, exercises, means, assessment of the competence in foreign languages reading.

Formulation of the problem. The formation of a foreign language competence in reading at the highest level is conditioned by the need to consider the issue in the context of a competent approach, which makes it possible to reconcile the problem with other language competences - components of foreign communication competence, the formation of which is the goal of teaching foreign languages in secondary education establishments.

Analysis of recent research on the problem. Many Ukrainian and foreign scholars: E. Passov, Z. Klychnikov, J. Berman, V. Plakhotnik, O. Bihich, H. Boretska, J. Hlushchenko, M. Denysenko, O. Petrenko, F. Grellet, used the methods of formation of foreign language competence. However, the problem can't be considered definitively resolved, as it requires clarification of the characteristics of the foreign language competence of reading at the highest level, the goals of its formation in pupils of secondary education institutions, the stages of forming the competence of reading in a foreign language.

Thus, the aim of the article is: to consider the general characteristics of foreign language competence in reading, the purpose of its formation in students; give description of exercises and tasks; to describe the means of formation the competence of reading at the highest level and control the level of its formation.

Presenting the main material. The main purpose of teaching foreign languages in the Council of Europe recommendations is to form a communicative competence that consists of the linguistic, speech and socio-cultural components. Communicative competence is the ability of students to apply in a particular form of communication their knowledge of the language. The specifics of competency education at English lessons are the acquisition of pupils of a foreign language in such a way, as to get skills of work in the group, to have different social roles, to communicate with native speakers. One of the types of communicative activities at foreign language classes is reading.

Reading in a foreign language as a communicative skills and communication means is an important form of speech activity and the most common way of foreign language communication. This is due to the fact that the process of reading synthesizes involuntary assimilation of speech phenomena in the process of mediated communication with the author of the text, the adoption of certain information contained in the text and the emotional and aesthetic perception of the artistic word. Working with the text extends the worldview of pupils, develops logic, intelligence, cognitive interests. It allows students to understand a foreign language in its sociocultural context, to understand its stylistic diversity, to digest its expressive potential, stimulates the autonomy of thinking, induces initiative speech (Bolotov, p. 11).

Reading is a receptive type of speech activity, which includes the technique of reading and understanding of what is read, and relates to the written form of speech. In this regard, the content and procedural aspects of the work of the reader are distinguished. The meaningful aspect of reading depends on procedural and is to achieve an understanding of the information perceived by the reader, due to the decoding of graphic symbols and semantic connections of the text.

Like other type of receptive activity - listening comprehension, reading is based on the recognition of the linguistic units of written text. Depending on the strength of the assimilation of the linguistic material and the level of the formation of 
the mechanisms of visual perception, the recognition process can be carried out quickly and directly, or at a slowed pace with elements of the recall (Passov, p. 3-4).

There are two basic levels of understanding of the text: the level of value and the level of content. The first is connected with the establishment of values of perceived linguistic units and their direct connections, the second - with the understanding of the content of the text as an integral linguistic unit. In this regard, the skills and abilities that provide understanding of the text are conventionally divided into two groups, although the processes of perception and comprehension occur simultaneously.

The first group is the skills associated with the technical aspect of reading. They provide a direct act of perception of graphic symbols and their correlation with the corresponding values. The second group is the skills that provide the semantic aspect of reading: the establishment of semantic connections between the linguistic units of the text, the achievement of understanding of the content, the intention of the author, that is, understanding the text as a complete speech work. A higher level of reading in English involves mastering the second group of skills and abilities. To achieve this level of comprehension, reading skills should be automated so that the pupil's attention is entirely focused on semantic immersion in the text.

E. I. Passov highlights the skills of foreign reading that are compulsory for pupils on the higher level. For pupils in the 10th form:

1. The ability to understand the basic idea, the meaning of the text.

2. Ability to choose material for reading depending on interests, desires, necessities and circumstances.

For students of the 11th grade the requirements are complicated:

1. The ability to understand the basic idea, the meaning of the text.

2. Ability to choose material for reading depending on interests, desires, necessities and circumstances.

3. Ability to read quickly enough to extract information that is needed to discuss problems.

4. Development of the ability to synthesize information from different sources (Passov, p. 10).

Therefore the motive for reading at the highest level as communicative activity is communication, and the purpose is to obtain the necessary information, and work with the text can pursue different goals: sometimes it is only necessary to determine what the text is about, in other cases, it is important to understand the basic or the new information, idea of the author, subtext. The necessary conditions for forming the competence of reading English at the highest level are the relevant principles of learning:

- a personal approach on lessons of English, which is to uncover the pupil's personal potential;

- the communicative nature of the English language learning process, which is implemented through the integration of various forms and teaching methods, for example: visualization of material, discussion of the material that was read in the form of a game or a report;

- compiling of material for reading in order to intensify cognitive activity of students;

- increasing interest in language learning through the use of computer and Internet technologies, for example: creating a presentation of the material that was read. 
To achieve the highest level in English reading, the following three groups of exercises are used at the lessons:

1) substantial identification. These are exercises in which a student must relate some statements to others. This means establishing their similarity or difference in terms of content. In this case, the following options for this type of exercise:

- find the phrases in the text that are similar in content to the data;

- determine whether the given phrases correspond to the content of the text;

- compile phrases (from data) that correspond to the content of the text.

The purpose of these exercises is the development of various mechanisms of reading: the mechanism of semantic guesswork, substantial anticipation, speed of reading.

2) Content search. Its options are as follows:

- point out phrases confirming a certain thesis;

- point out what characterizes someone/something, the situation as a whole;

- point out the causes of what happened, is happening;

- point out problems that concern anyone.

The main task of these exercises is to develop the mechanisms of logical understanding. The actions that the pupils perform when performing these exercises are not accidentally called a search, since the pupils are really looking for what is required in the read, and are looking for it on the basis of how much they understood from the text. If they don't understand the basic thoughts of the text, the search will not take place.

3) Semantic choice. These exercises include the following options:

- choose a suitable title from the data;

- choose the correct answer within the suggested one;

- choose from each paragraph of the text for one phrase that conveys the meaning of the whole paragraph.

The main task of these exercises is the development of the mechanism of logical understanding, they also develop a semantic conjecture, improve the reading technique and the mechanism of internal speech hearing. It is desirable that the teacher is not satisfied with the correct choice of ready-made answers, because of the random of the choice, so can ask to explain the choice of the pupil or to confirm it with examples from the text.

All three groups of exercises are characterized by two very important for learning factors of properties and parameters. First, their execution is always associated with the constant contact with the text in a limited time that leads to the development of the ability to read. Second, the implementation of these exercises eliminates the need for special, purposeful control. The ability to read allows pupils, in their further work and training, to use literature in a foreign language to find information on the speciality, to satisfy their readership or creative interests, and to improve the skills of oral speech.

Conclusions and prospects for further research. Study of reading should satisfy the needs of practical application of foreign language knowledge gained in the classroom; to increase the time of students' communication with foreign language material helps to transfer read information to others and also gives the ability to rethink information obtained through reading, mind analyzing and discussing, aims to considering reading not only as receptive but also reproductive activity. The theoretical basis of the methodology of reading on lessons should have 
general educative laws and principles for the construction of any learning process. They are the basis of optimization and successful training. Therefore, the development of the topic of this problem should be further studied in our subsequent publications.

\title{
REFERENCES:
}

Bolotov, V. (2003). Kompetentnostnaya model: ot idei k obrazovatelnoy paradigme [Competence bodel: from an Idea to the Educational Paradigm]. Pedagogika, 10, ss. 7-13. [in Russian].

Passov, E. (2000). Programma-kontseptsiya kommunikativnogo inoyazychnogo obrazovaniya [Program-concept of the Communicative Innovation Education]. Moskva: Prosveshcheniye. 174 s. [in Russian].

Grellet, F. (1994). Developing Reading Skills. - Cambridge University Press.

Mc Rae, John, Boardman, Roy. Reading between lines (2001). - Cambridge University Press.

Hlushchenko, Zh. (2010). Orhanizatsiia chytannia na urokakh inozemnoi movy [Organization of the reading on the foreign language classes]. Anhliiska mova ta literatura, 16-18, ss. 2-4.

Zhukova, I. (1998). Rabota s tekstamy na uroke anhlyiskoho yazika [Work with Texts at the English Classes]. Inostrannye yazyki v shkole, 1. [in Russian].

Boretska, H. (2012). Metodyka formuvannia inshomovnoi kompetentnosti u tekhnitsi chytannia [Methods of Formation of the Foreign Language in Reading Technique]. Inozemni movy, 1, ss. 38. [in Ukrainan].

\section{ФОРМУВАННЯ КОМПЕТЕНТНОСТІ ЧИТАННЯ АНГЛІЙСЬКОЮ МОВОЮ НА ВИЩОМУ СТУПЕНІ ВИВЧЕННЯ МОВИ У СЕРЕДНІХ НАВЧАЛЬНИХ ЗАКЛАДАХ}

\author{
Безкоровайна Ольга \\ доктор педагогічних наук, професор, \\ завідувач кафедри методики \\ викладання іноземних мов \\ Рівненського державного гуманітарного університету, \\ м. Рівне, Україна \\ ORCID : 0000-0001-7144-9946, \\ e-mail: olg2686@gmail.com \\ Демчук Тетяна \\ здобувач освітнього рівня «бакалавр» \\ факультету іноземної філології \\ Рівненського державного гуманітарного університету, \\ м. Рівне, Україна \\ ORCID: 0000-0003-0783-6540, \\ e-mail: demchuktania.dt@gmail.com
}

Анотація. У статті процес читання розуміється як складний процес. Читання синтезує у собі мимовільне засвоєння мовних явищ, прийомів певної інформації, яка міститься у тексті та емоційно-естетичне сприйняття прочитаного. Робота 3 текстом розширює світогляд учнів, розвиває логіку, інтелект, пізнавальні інтереси. Однак існує велика різниця між читанням рідною та іноземною мовами, висвітлена в статті, а також вправи та підходи для читання англійською мовою для вищого освітнього рівня. 
В даній статті читання розглядається як один 3 видів комунікативної діяльності в іноземній мові. Досліджено загальну характеристику компетентності читання іноземною мовою, мету іiї формування у школярів; представлений опис вправ і завдань; описані засоби формування компетенції читання на найвищому рівні і контроль рівня його формування.

У статті висвітлений змістовний аспект читання і два базові рівні розуміння тексту; визначені принципи навчання, які $є$ необхідними умовами для формування компетенції читання англійською мовою на найвищому рівні; зазначено, що теоретичні основи методології читання на уроках повинні опиратися на освітні закони і принципи побудови навчального процесу. Доведено, що здатність читати дозволяє учням у подальшій роботі та навчанні використовувати літературу іноземною мовою, щоб знайти інформацію за спеціальністю, задовольнити свої читацькі чи творчі інтереси, а також вдосконалити навички. усного мовлення.

Для вирішення поставлених завдань були використані загальнонаукові методи теоретичних і емпіричних досліджень, які взаємно доповнюють один одного і забезпечують можливість всебічного знання предмета дослідження. На етапі теоретичних досліджень використовувалися такі методи, як аналіз психологопедагогічної літератури, порівняння та узагальнення фактів. Інші методи були вирішальними в розробці комплексу вправ для викладання англійської мови для студентів старших курсів.

Ключові слова: компетентність читання англійською мовою, мовна обізнаність, етапи, вправи, засоби, оцінка компетентності читання іноземною мовою.

Стаття надійшла до редакиії 08.05.2019 p. 